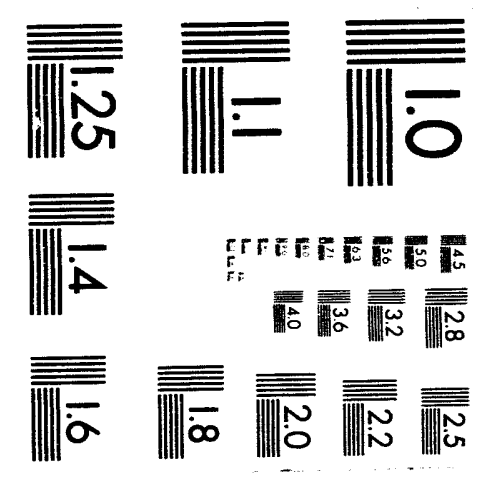



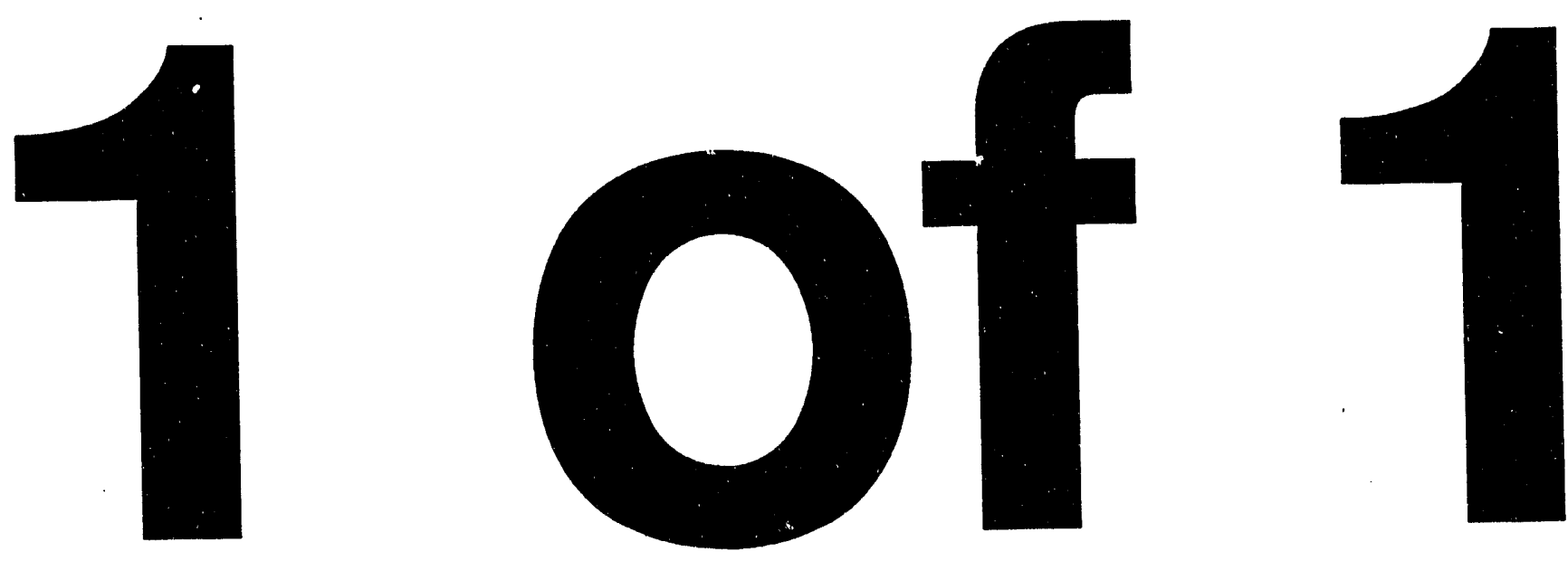


\section{Hydrologic Analysis of Steel Creek and L Lake and the Effects of Flow Reduction on Steel Creek Habitat (U)}

B. R. del Carmen and M. H. Paller

\footnotetext{
Westinghouse Savannah River Company Savannah River Site Aiken, SC 29808
}

Prepared for the U.S. Department of Energy under contract no. DE-AC09-89SR18035 


\section{Disclaimer}

This report was prepared as an account of work sponsored by an agency of the United States Government. Neither the United States Government nor any agency thereof, nor any of their employees, makes any warranty, express or implied, or assumes any legal liability or responsibility for the accuracy, completeness, or usefulness of any information, apparatus, product, or process disclosed, or represents that its use would not infringe privately owned rights. Reference herein to any specific commercial product, process, or service by trade name, trademark, manufacturer, or otherwise does not necessarily constitute or imply its endorsement, recommendation, or favoring by the United States Government or any agency thereof. The views and opinions of authors expressed herein do not necessarily state or reflect those of the United States Government or any agency thereof. 


\section{Hydrologic Analysis of Steel Creek and L Lake and the Effects of Flow Reduction on Steel Creek Habitat (U)}

B. R. del Carmen and M. H. Paller

Westinghouse Savannah River Company

Savannah River Site

Aiken, SC 29808

Prepared for the U. S. Department of Energy under contract No. DE-AC09-89SR18035 


\section{Contents}

Abstract 1

Executive Summary 1

Introduction 1

Methods 2

Steel Creek Base Flow 2

Pen Branch Comparison 2

Steel Creek Watershed Analysis 2

L Lake Water Balance 3

Evaporation 3

\section{Results and Observations 3}

Steel Creek Base Flow 3

L Lake Water Balance 3

Inflows 3

Outflows 4

Residual 4

Effects of Flow Reduction 4

Effects of Flow Reduction on Fish Community 4

Conclusions 5

References 5

Tables 7

Figures 11 


\title{
Hydrologic Analysis of Steel Creek and L Lake and the Effects of Flow Reduction on Steel Creek Habitat (U)
}

\author{
B. R. del Carmen and M. H. Paller
}

\section{Abstract}

This report was prepared to support a proposal to eliminate the EIS mandated spring flow requirements in Steel Creek below $L$ Lake. The base flow in Steel Creek below L Lake was estimated using historical data. The water balance of $L$ Lake was studied to evaluate the effects of flow reduction on the Steel Creek hydrologic system. The base flow in Steel Creek below L Lake is estimated as $0.28 \mathrm{cms}(10 \mathrm{cfs})$. A reduction in L Lake discharge to $0.28 \mathrm{cms}$ will result in a fish community similar to the one that existed before the impoundment of $L$ Lake.

\section{Executive Summary}

In support of the revision of the Steel Creek minimum flow requirements, an analysis of the historical (i.e., pre-L Lake) natural flow in Steel Creek and a water balance study of $\mathrm{L}$ Lake were performed. The historical natural flow in Steel Creek below the L Lake dam was estimated by comparison with a similarly sized drainage area in the Pen Branch watershed and by extrapolation from a smaller drainage area within the Steel Creek watershed. The historical natural flow in Steel Creek below L Lake is approximately 0.28 cubic meters per second (cms) (10 cubic feet per second, cfs). A reduction in $\mathrm{L}$ Lake discharge to historical base flow levels of approximately $0.28 \mathrm{cms}$ is likely to result in reductions in stream dimensions to levels that wiil favor those species of fish typical of first and second order streams. The ultimate result would be a fish community similar to the one that existed in Steel Creek prior to the impoundment of $\mathrm{L}$ Lake. However, due to the time required for Steel Creek physical channel features to equilibrate to the lower natural flow, readjustment of the fish community may not occur immediately.

The average annual water balance of $L$ Lake was analyzed to determine the significance of various water balance components and to estimate the overall effects of reducing the discharge from L Lake to Steel Creek. The water balance of $\mathrm{L}$ Lake has been dominated by Savannah River pumping inflow from L Area and discharge through the dam into Steel Creek. Natural inflow to L Lake from precipitation $(0.16 \mathrm{cms})$ and natural Steel Creek flow above L Lake $(0.04 \mathrm{cms})$ combine to average about $0.20 \mathrm{cms}$. Average lake water loss to evaporation $(0.14 \mathrm{cms})$ and seepage $(0.04$ cms) is approximately $0.18 \mathrm{cms}$. With a reduction in lake discharge to the base flow of $0.28 \mathrm{cms}$, approximately $0.26 \mathrm{cms}$ (4100 gallons per minute, $\mathrm{gpm}$ ) additional inflow is required to maintain lake level. Due to uncertainty in lake seepage (which may be as much as $0.20 \mathrm{cms})$, a greater inflow $(0.42 \mathrm{cms}$, $6700 \mathrm{gpm}$ ) may be needed to maintain lake level. Because this water balance is based on average annual values, the daily inflow rates needed to maintain lake level are expected to fluctuate slightly with fluctuations in precipitation.

\section{Introduction}

The Environmental Impact Statement, L-Reactor Operation (L-EIS) (DOE 1984) specifies minimum flow requirements in Steel Creek downstream from L Lake during times of reactor outage. The L-EIS specifies, "If long reactor outages should occur during the spawning period (nominally March-June), flow would be maintained at a rate of about 3 cubic meters per second (cms). For long outages at other times, only base flow conditions would occur in Steel Creek."

The L-EIS requirements were based on the condition of full reactor flow, approximately $10 \mathrm{cms}$, as the normal flow regime of Steel Creek. With the restart of L Reactor in 1985, it was assumed that the stream and biota of Steel Creek would adapt to the higher flow regime associated with reactor operation. This adaptation included the use of stream margins and backwater areas for reproduction by spawning fish and reproducing insects. Consequently, the L-EIS minimum flow requirements were designed to mitigate against dewatering of these stream margin areas; thus preventing the potential loss of fish larvae and eggs and invertebrate populations. Under the current cold standby status of L Reactor, it is unlikely that Steel Creek will ever again experience the high flows that were associated with reactor operation. Therefore, it 
has been proposed that the spring high flow requirement of the L-EIS be eliminated as a step in restoring Steel Creek to a more natural hydrologic regime (Gladden 1993).

The L-EIS specifies that base flow conditions should occur in Steel Creek during long reactor outages at times other than the spawning season. With the elimination of the spring flow requirement, the target for establishing discharge from L Lake to Steel Creek is "base flow conditions". Base flow conditions should therefore be determined for the reach of Steel Creek just below the dam. Previous Steel Creek base flow analyses have been made using flow records from the U. S. Geologic Survey (USGS) gage at Old Hattiesville Bridge (USGS \#02197359; gage operated from March 1974-September 1985). This gage howe. represented the full Steel Creek watershed including the major tributary, Meyers Branch as well as discharge from both $\mathrm{L}$ and $\mathrm{P}$ Areas.

Since the filling of L Lake in Noveniber 1985, flow in Steel Creek below the lake has been regulated by discharge through the dam. Lake discharge is a significant component of the L Lake water balance. Therefore, to gain a comprehensive understanding of the effects of flow reduction on the Steel Creek hydrologic system, the water balance of L Lake must be investigated. This study focuses on quantifying the base flow in Steel Creek, evaluating the water balance of L Lake, and quantifying the effects of flow reduction on Steel Creek aquatic habitat.

\section{Methods}

\section{Steel Creek Base Flow}

Base flow is the groundwater driven day-to-day natural flow of a stream. During a storm event a portion of the total precipitation infiltrates the soil and recharges the groundwater in the shallow aquifers. This shallow groundwater travels through the upper aquifers until it reaches surface water streams. In a study of two other Coastal Plain streams on SRS, Williams and Pinder (1990) concluded that approximately $95 \%$ of the total streamflow was due to groundwater driven base flows. Consequently, in this study the assumption is made that total measured streamflow is equal to base flow.

Since Steel Creek flow was not measured in the location of the dam before the impoundment of $\mathrm{L}$ Lake, the base flow must be estimated using discharge records from other sites. The method of estimating ungaged flow is dependent on the characteristics of the watershed as well as the available data. The usual approach for determining base flow is to employ some type of hydrograph separation technique (Bras 1990). However, the lack of unregulated streamflow data prevents the use of hydrograph separation techniques. The historical base flow in Steel Creek was estimated using two methods. The first method examines the flow in an adjacent unimpaired and unregulated stream of similar size. The second method estimates the natural flow below L Lake by extrapolating from a smaller drainage area representing the headwaters of Steel Creek. Estimates of drainage areas were taken from a 1 inch:48000 inches USGS SRS topographic map.

\section{Pen Branch Comparison}

The flow in Pen Branch at SRS Road B was evaluated to estimate the natural flow in Steel Creek below $\mathrm{L}$ Lake (Figure 1). The Pen Branch study area (23.6 kilometers $^{2}$ ) is approximately equal in size to the Steel Creek drainage area above the dam (23.0 kilometers $\left.{ }^{2}\right)$; both drainage areas represent second order streams. The Pen Branch flow at Road B has been gaged by the USGS (USGS \#021973471) since October 1983.

\section{Steel Creek Watershed Analysis}

In humid regions where watersheds are typically homogeneous throughout the region, the spatial distribution of monthly or seasonal rainfall does not significantly vary from one portion of the basin to another. Consequently, estimated streamflow $\mathrm{Q}_{S}$ at any site $s$ can be based on the area $\mathrm{A}_{s}$ above site $s$ and the streamflow $\mathrm{Q}_{s}$ ' and area $\mathrm{A}_{s}$ ' above the nearest or most representative gage site $s^{\prime}$ (Loucks et al. 1981).

$$
\mathrm{Q}_{s}=\mathrm{Q}_{s}{ }^{\prime}\left[\mathrm{A}_{s} / \mathrm{A}_{s}{ }^{\prime}\right]
$$

Equation 1 applies to situations in which the gage site $s^{\prime}$ is downstream of the site $s$ of interest as well as situations in which the gage site $s^{\prime}$ is upstream of the site $s$ of interest. Equation 1 is applied to the Steel Creek watershed to estimate the natural historical flow in Steel Creek below L Lake.

The gaged site selected for this analysis is represented by the USGS station above SRS Road B (USGS \#021973515) (Figure 1). This gage represents an area of 5.9 kilometers $^{2}$. Complete yearly data is available for water years (October-September) 1987-1992. The gage above Road B is influenced by discharge from 
SRS operations in P Area. Discharge from P-Area operations is gaged in the P-013 outfall canal (USGS \# 02197351) (Figure 1). Natural flows at the station above Road B are obtained by subtracting the gaged P013 discharge.

\section{Lake Water Balance}

The water balance of $\mathrm{L}$ Lake is composed of eight terms: pumping water inflow (Qpump), inflow from Steel Creek (SCin), precipitation (P), outflow to Steel Creek (SCout), evaporation (E), seepage (GW), residual or error term (R), and change in storage (DS/DT).

\section{Qpump+SCin+P-SCout-E-GW+R=DS/DT}

Yearly average data is used to evaluate the historical L Lake water balance for three water years, 1989, 1990, and 1992. An analysis of gage height records (USGS \#02197353) shows that the average change in storage is negligible. The DS/DT term is therefore equal to 0 . Pumping inflow from L Area is gaged at the L-007 outfall (USGS \#021973525) (Figure 1). Steel Creek inflow is gaged approximately 1.3 kilometers upstream of Road B (USGS \#021973515) (Figure 1). L Lake discharge to Steel Creek is measured in the dam spillway, 0.6 meters downstream from the headwall of the spillway (USGS \#021973537) (Figure 1). In the L Lake area, the SRTC Weather Center compiles daily precipitation data for gages at Barricade 5, approximately 8.0 kilometers southeast of L Lake, and at 100-P, approximately 3.7 kilometers northeast of $\mathrm{L}$ Lake. Precipitation at $\mathrm{L}$ Lake is calculated by averaging the data from Barricade 5 and 100-P. Yearly total precipitation is converted to flow by multiplying by the lake area (4.186 kilometers $\left.{ }^{2}\right)$. Seepage is calculated from estimates of hydraulic conductivity, hydraulic gradient, and flow area. Given the low vertical hydraulic conductivity, $1.6 \times 10^{-3}$ meters/day, it is assumed that flow in the vertical direction is not significant for this water balance analysis (Haselow et al. 1989). The residual term is analyzed by balancing the inflow and outflow terms.

\section{Evaporation}

Lake evaporation is computed using the energy budget method (Bras 1990). Average monthly solar radiation data, average monthly air temperature data, and average monthly humidity data were obtained from the SRTC Weather Center. Radiation, air temperature, and humidity data are measured at the Central Shops weather tower, approximately 5.6 kilometers northwest of L Lake. L Lake water temperature is measured by the USGS (USGS \#02197353). Data on average cloud cover for the area was obtained from climatological data from Bush Field in Augusta, GA (NOAA 1991). Yearly total evaporation is converted to flow by multiplying by the lake area $\left(4.186\right.$ kilometers $\left.^{2}\right)$.

\section{Results and Observations}

\section{Steel Creek Base Flow}

The average flow in Pen Branch at Road B during water years $1984-1992$ is $0.20 \mathrm{cms}$. Both the Pen Branch and Steel Creek study areas contain welldrained soils of the Fuquay-Blanton-Dothan Association and the Vaucluse-Alley Association (Rogers 1990). The recharge capacities of the two drainage areas are therefore closely related. Based on the similarities of the two drainage areas it is estimated that the natural flow in Steel Creek below L Lake is approximately equal to the average flow in Pen Branch at Road B.

The natural flow, without P-013 influences, in Steel Creek above Road B during water years 1987-1992 is approximately $0.04 \mathrm{cms}$. Applying equation 1 , the estimated flow downstream of L Lake is approximately $0.17 \mathrm{cms}$. In the SRS region, 1985-1989 is recognized as a drought period (SAIC 1989). The 1985-1989 drought years represent a significant portion of the period of record for both base flow computation approaches. From the similar results of the two approaches and recognizing the influence of the drought years, it is concluded that the base flow in Steel Creek below L Lake is approximately $0.28 \mathrm{cms}$ $(10 \mathrm{cfs})$. This result is consistent with a previous study that estimated SRS groundwater recharge to local streams as approximately $0.01 \mathrm{cms} /$ kilometers $^{2}$ (Hubbard 1988).

\section{Lake Water Balance}

\section{Inflows}

Table 1 presents a summary of the water balance for the three yearly periods. Historically, Savannah River pumping inflow from L Area through the L-007 outfall represents $94 \%$ of the total inflow to $L$ Lake. The average inflow through the $\mathrm{L}-007$ outfall for the three years is $2.99 \mathrm{cms}$. For the three years, the average inflow from Steel Creek is $0.09 \mathrm{cms}$. The average 
annual precipitation for the three years, 112 centimeters (44 inches) is slightly less than the historical (1952-1992) SRS average precipitation of 122 centimeters ( 48 inches).

\section{Outflows}

L Lake outflow is primarily discharge to Steel Creek. The average discharge over the three years is $2.16 \mathrm{cms}$. Using the energy budget approach, annual evaporation loss is approximately 107 centimeters ( 42 inches). The most difficult term of the water balance to estimate is seepage. Inspection of SRS water table maps indicates that L Lake is gaining groundwater in its most northern section, near Road B. However, the majority of the lake is losing water to the surface water system. Given an average lake depth of $12.19 \mathrm{~m}$, L Lake only interfaces with the "upper aquifer" zone of the Upper Three Runs aquifer. In the area surrounding L Lake, the top $12.19 \mathrm{~m}$ of soil is composed primarily of medium and coarse silty and clayey sands and silty and sandy clays (Tuck et al. 1993). Modeling studies in L Area have used a horizontal hydraulic conductivity estimate of $3.0 \mathrm{~m} /$ day for the upper aquifer zone of the Upper Three Runs aquifer (Haselow 1989). Using this hydraulic conductivity, seepage out of the lake is estimated as $0.04 \mathrm{cms}$. Given the difficulty of estimating seepage out of lakes, it is reasonable to assume a possible error of $\pm 500 \%$. This uncertainty could increase the amount of seepage out of the lake to $0.20 \mathrm{cms}$.

\section{Residual}

The average residual for the three years is $0.88 \mathrm{cms}$ or $27 \%$ of the total lake inflow. This residual represents a surplus of inflow or a deficit of outflow. Analysis on a monthly basis does show a seasonal trend with higher residuals in the months of April to October. These are also the months with the highest inflows of pumping water and the highest lake discharges. Error in precipitation measurements is usually in the range of \pm $5 \%$. Evaporation computed by the energy budget method is usually considered to be within $10-20 \%$ of the true value (Winter 1981). Even an unlikely increase in seepage by an order of magnitude to $0.4 \mathrm{cms}$ and an increase in evaporation by $20 \%$ to 128 centimeters would only decrease the average residual by approximately one-half. This indicates that a significant portion of the residual may be the result of error with the gaged inflow at L-007 or the gaged outflow at the dam. It is unlikely that there is significant error with the measurements at the L-007 gage considering that flow is gaged in a boxed concrete canal. However, there are suspected historical equipment malfunctions with the gage located in the $\mathrm{L}$ Lake outfall spillway (USGS, personal communication).

\section{Effects of Flow Reduction}

A reduction in the discharge to Steel Creek to the natural flow of $0.28 \mathrm{cms}$ would have a significant effect on the L Lake water balance. Precipitation (122 centimeters/year or $0.16 \mathrm{cms}$ ) and natural Steel Creek inflow without $P$ Area operations flow $(0.04 \mathrm{cms})$ combine to form the natural inflow to $L$ Lake of 0.20 cms. Assuming average evaporation of 107 centimeters/year $(0.14 \mathrm{cms})$ and seepage of $0.04 \mathrm{cms}$, lake discharge equal to the base flow of $0.28 \mathrm{cms}$ would require additional inflow of $0.26 \mathrm{cms}(4100$ $\mathrm{gpm})$ to maintain lake level. With a higher estimate of seepage $(0.20 \mathrm{cms})$, a greater inflow $(0.42 \mathrm{cms}, 6700$ $\mathrm{gpm})$ would be needed to maintain lake level. This water balance analysis is based on average annual values. Therefore, the quantity of inflow needed to maintain lake level would naturally fluctuate as precipitation fluctuates.

If pumping inflow from the Savannah River and outflow to Steel Creek were ceased and assuming that precipitation is approximately equal to evaporation, lake seepage losses would eventually equilibrate with natural inflow from Steel Creek headwaters. Given an estimated seepage of $0.04 \mathrm{cms}$, the lake would remain at its current level of 190 feet. Due to uncertainty in groundwater flow, seepage losses may be significantly higher than $0.04 \mathrm{cms}$. A higher estimate of seepage $(0.20 \mathrm{cms})$ produces a new lake area of 207 acres and a stage of approximately 147 feet. This represents an $80 \%$ reduction of the current lake area.

\section{Effects of Flow Reduction on Fish Community}

Fish assemblages on the SRS are strongly affected by stream depth, width, and current velocity (Meffe and Sheldon 1988, Paller 1992). The species that occur in comparatively narrow, shallow streams differ markedly from those that occur in deeper, wider streams (Paller 1992). The most abundant fish in first and second order streams include yellowfin shiner, bluehead chub, pirate perch, tessellated darter, several species of madtom, and dollar sunfish among others (Table 2). In contrast, the most abundant fish in third and fourth order streams include spotted sucker, largemouth bass, 
coastal shiner, dusky shiner, American eel, bluegill, and redbreast sunfish. Stream order correlates strongly with stream size, with first order streams being among the smallest on the SRS and fourth order streams being among the largest.

Steel Creek fish assemblages were sampled in 1984 and 1985 at a point slightly upstream from the confluence of Steel Creek and Meyers Branch and approximately $1 \mathrm{~km}$ downstream from the L Lake dam. At the time of this sampling, L Lake had not yet been constructed and base flow in Steel Creck was typical of second order streams on the SRS (see section Results and Observations: Steel Creek Base Flow). Average width was $3.5 \mathrm{~m}$ and average depth $22 \mathrm{~cm}$; both values are fairly similar to the average widths and depths measured in 15 second order SRS streams during 1990 (Table 3). Electrofishing samples indicated that the fish assemblage in this portion of Steel Creek during 1984 and 1985 (Aho et al. 1986) was numerically dominated by yellow fin shiner, bluehead chub, pirate perch, spotted sunfish, tessellated darter, and madtoms (Table $4)$, species common in unimpacted first and second order SRS streams (Table 2).

With the filling of L Lake and initiation of L-Reactor operations in 1986, the mid reaches of Steel Creek began to receive up to approximately $11 \mathrm{cms}$ of water over the L Lake dam. The resulting width and depth increases (Table 3 ) caused substantial charges in the fish assemblages as indicated by samples taken at the same location as during 1988 (Table 4). While shiners were not identified to species in 1988; hence, cannot be directly compared to the shiner species collected in $1984 / 1985$, other species showed marked changes in percent abundance, including bluehead chub and pirate perch, which virtually disappeared, and redbreast sunfish, yellow bullhead, and flat bullhead which markedly increased.

Electrofishing samples have not been collected from the previously described sample station since 1988 . Therefore, we cannot document the current status of the Steel Creek fish community nor the physical dimensions of the creek. However, the proposed plan to reduce L Lake discharge to historical (i.e., pre-L Lake) base flow levels of approximately $0.28 \mathrm{cms}$ is likely to result in reductions in stream dimensions to levels that will favor those species of fish typical of first and second order streams and ultimately result in a fish community similar to the one that existed in Steel Creel before the impoundment of L Lake. However, readjustment of the fish community may not occur immediately because the physical features of the Steel
Creek channel (such as width, depth, and substrate composition) will probably require time to equilibrate to the restored historical base flows.

\section{Conclusions}

The computation of base flow is highly limited by the availability of stream discharge data. In the case of Steel Creek, no unregulated discharge data is available for either the period before the impoundment of $\mathrm{L}$ Lake or the period after impoundment. However, with the analysis of the headwater drainage area of Steel Creek, it is possible to estimate the flow at the location below L Lake. The base flow estimate of the Steel Creek watershed analysis is confirmed by comparison with the flow in a neighboring reach of the similarly sized second-order Pen Branch. Evaluating these flows over their period of record with recognition of the drought influence produces a Steel Creek base flow below L Lake equal to approximately $0.28 \mathrm{cms}$. The base flow estimate represents an average value. During storm periods, significantly higher flows could be expected due to storm runoff.

In the historical water balance of $\mathrm{L}$ Lake, precipitation, natural inflow, evaporation, and seepage were relatively insignificant compared to the pumping water inflow and the lake discharge. With the reduction in discharge however precipitation, natural inflow, evaporation, and seepage will each play more significant roles in the water balance of $L$ Lake. This analysis has attempted to evaluate the effects of discharge reduction on the water balance. However, it must be recognized that the questionable historical data and the limitations of characterizing the complete groundwater flow picture make it is impossible to predict the exact reaction of the lake water balance under future conditions.

\section{References}

Aho, J.M., C.S. Anderson, K.B. Floyd, M.T. Negus, and M.R. Meador, (1986), Patterns of fish assemblage structure and dynamics in waters of the Savannah River Plant. Aiken, SC: Savannah River Ecology Laboratory, University of Georgia (SREL-27).

Bras, Rafael L., (1990), Hydrology, Addison-Wesley Publishing Company, Inc., Reading, MA.

DOE (J.S. Department of Energy), (1984), 1984 Environ nental Impact Statement L-Reactor Operation, Savannah River Plant, DOE/EIS-0108. 
Gladden, J. B., (1993), Memorandum to J. L. Keyes 6/30/93, Flow in Steel Creek Downstream from L Lake, SRT-ESS-93-0499.

Haselow, J. S., V. Price, D. E. Stephenson, H. W. Bledsoe, and B. B. Looney (1989), Reactor Operation Environmental Information Document, Volume 1, Geology, Seismology, Subsurface Hydrology, WSRCRP-89-00815.

Heuer, J. H., and L. A. Kissick, (1989), Steel Creek Fish: L Lake/Steel Creek Biological Monitoring Program, January 1986-December 1988, Prepared for E.I. duPont de Nemours \& Company by Normandeau Associates Inc., Aiken, SC, NAI-SR-87.

Hubbard, J. E., D. E. Stephenson, J. L. Steele, and D. E. Gordon, (1988), Water Resource Management Planning Guide For Savannah River Plant, IPST-88835.

Loucks, D. P., J. R. Stedinger, and D. A. Haith, (1981), Water Resource Systems Planning and Analysis, Prentice-Hall, Inc., Englewood Cliffs, N.J.

Meffe, G.K., and A.L. Sheldon, (1990), Postdefaunation recovery of fish assemblages in southeastern blackwater streams, Ecology 71:826-860.

NOAA, (1991), Local Climatological Data Annual Summary With Comparative Data, Augusta, GA, ISSN-0198-1587.

Paller, M.H., (1992), Stream fisheries characterization study, Westinghouse Savannah River Company, Aiken, SC WSRC-RP-92-1034.

Paller, M.H., (1993), Relationships between fish assemblage structure and stream order in South Carolina coastal plain streams. In press. Transactions of the American Fisheries Society.

Rogers, V. A., (1990), Soil Survey of Savannah River Plant Area, Parts of Aiken, Barnwell, and Allendale Counties, South Carolina, U. S. Department of Agriculture, Soil Conservation Service.

SAIC (Science Applications International Corporation), (1989), Final Report: Analysis of SRP Impacts on the Savannah River During Low Flow Conditions, SAIC, Oak Ridge, TN.
Tuck, D. M., R. K. Aadland, C. A. Eddy Dilek, J. S. Haselow, B. B. Looney, A. L. Stieve, and R. N. Strom, (1993), Environmental Information Document: Geology and Hydrogeology of the Savannah River Site, WSRC-TR-93-147.

Williams, J. B. and J. E. Pinder, (1990), Groundwater Flow and Runoff in a Coastal Plain Stream, Water Resources Bulletin, 26(2):343-352.

Winter, T. C., (1981), Uncertainties in Estimating the Water Balance of Lakes, Water Resources Bulletin, 17(1): 82-115. 


\section{Tables}

Table 1. L Lake Water Balance for Water Ycars 1989, 1990, 1992

\begin{tabular}{|c|c|c|c|c|c|c|c|}
\hline \multirow{2}{*}{$\begin{array}{l}\text { Water } \\
\text { Year }\end{array}$} & \multicolumn{3}{|c|}{ Qin } & \multicolumn{4}{|c|}{ Qout } \\
\hline & $\begin{array}{l}\text { Qpump } \\
\text { (cms) }\end{array}$ & $\begin{array}{l}\begin{array}{l}\text { SCin } \\
(\mathrm{cms})\end{array} \\
\end{array}$ & $\begin{array}{l}P \\
(\mathrm{cms})\end{array}$ & $\begin{array}{l}\text { SCout } \\
\text { (cms) }\end{array}$ & $\begin{array}{l}E \\
(\mathrm{cms})\end{array}$ & $\begin{array}{l}\mathrm{GW} \\
(\mathrm{cms})\end{array}$ & $\begin{array}{l}R \\
(\mathrm{cms})\end{array}$ \\
\hline 1989 & $\begin{array}{l}3.23 \\
(94)^{\mathrm{a}}\end{array}$ & $\begin{array}{l}0.03 \\
(1)\end{array}$ & $\begin{array}{l}0.16 \\
(5)\end{array}$ & $\begin{array}{l}2.26 \\
(66)\end{array}$ & $\begin{array}{l}0.14 \\
(4)\end{array}$ & $\begin{array}{l}0.04 \\
(1)\end{array}$ & $\begin{array}{l}0.98 \\
(29)\end{array}$ \\
\hline 1990 & $\begin{array}{l}2.97 \\
(91)\end{array}$ & $\begin{array}{l}0.17 \\
(5)\end{array}$ & $\begin{array}{l}0.14 \\
(4)\end{array}$ & $\begin{array}{l}1.88 \\
(58)\end{array}$ & $\begin{array}{l}0.14 \\
(4)\end{array}$ & $\begin{array}{l}0.04 \\
(1)\end{array}$ & $\begin{array}{l}1.22 \\
(37)\end{array}$ \\
\hline 1992 & $\begin{array}{l}2.77 \\
(93)\end{array}$ & $\begin{array}{l}0.06 \\
(2)\end{array}$ & $\begin{array}{l}0.15 \\
(5)\end{array}$ & $\begin{array}{l}2.35 \\
(79)\end{array}$ & $\begin{array}{l}0.14 \\
(5)\end{array}$ & $\begin{array}{l}0.04 \\
\text { (1) }\end{array}$ & $\begin{array}{l}0.45 \\
(15)\end{array}$ \\
\hline
\end{tabular}

a Values in parentheses are percentages of total inflow to L Lake 
Table 2. Mean percent abundance of fish species in first, second, third, and fourth order streams on the South Carolina coastal plain (Paller 1993). Also shown are the results of one-way analyses of variance of the differences. $^{\text {a }}$

Stream order

\begin{tabular}{lrrrrr}
\cline { 2 - 4 } Variable & $1 \& 2$ & 3 & 4 & F-test & Probability \\
\hline & & & & & \\
Yellowfin shiner & $28.0^{\mathrm{a}}$ & 17.8 & 7.7 & 4.70 & 0.035 \\
Pirate perch & 23.1 & 9.4 & 3.1 & 39.22 & $<0.001$ \\
Bluehead chub & 8.7 & 7.1 & 0.4 & 8.27 & 0.006 \\
Creek chub & 1.9 & 0.2 & 0.0 & 17.18 & $<0.001$ \\
Dollar sunfish & 1.7 & 1.2 & 0.4 & 7.70 & 0.008 \\
Spotted sunfish & 2.1 & 7.5 & 4.4 & 2.62 & 0.112 \\
Bluegill & 0.8 & 1.1 & 2.9 & 5.78 & 0.020 \\
Tessellated darter & 1.7 & 2.2 & 0.2 & 3.87 & 0.055 \\
Yellow bullhead & 2.2 & 1.7 & 0.3 & 9.71 & 0.003 \\
Madtom & 3.2 & 2.1 & 0.9 & 4.29 & 0.044 \\
Creek chubsucker & 2.7 & 1.9 & 2.5 & 0.01 & 0.909 \\
Blackbanded darter & 0.6 & 1.8 & 1.9 & 4.10 & 0.049 \\
Redfin pickerel & 3.0 & 3.0 & 1.1 & 5.46 & 0.024 \\
Warmouth & 0.5 & 0.7 & 0.8 & 0.84 & 0.365 \\
Coastal shiner & 1.4 & 3.3 & 4.1 & 6.07 & 0.018 \\
Sailfin shiner & 1.3 & 0.6 & 5.7 & 4.76 & 0.441 \\
American eel & 0.6 & 2.5 & 6.3 & 35.59 & $<0.001$ \\
Largemouth bass & 0.4 & 1.2 & 7.1 & 26.47 & $<0.001$ \\
Chain pickerel & $<0.1$ & 1.2 & 2.5 & 28.76 & $<0.001$ \\
Redbreast sunfish & 3.8 & 7.3 & 7.1 & 4.33 & 0.043 \\
Spotted sucker & 0.0 & 0.5 & 12.4 & 60.37 & $<0.001$ \\
Dusky shiner & 5.4 & 6.1 & 15.0 & 5.17 & 0.028 \\
& & & & &
\end{tabular}

a Percents were arcsine transformed for analysis

b Degrees freedom for all tests equal 2,44 
Table 3. Average width, depth, and current velocity in second, third, and fourth order SRS streams and in Steel Creek before (1984 \& 1985) and during (1988) the operation of L Reactor.

\begin{tabular}{|c|c|c|c|c|c|}
\hline \multirow[b]{3}{*}{ Variable } & \multicolumn{3}{|c|}{ SRS streams ${ }^{\mathrm{a}}$} & \multicolumn{2}{|c|}{ Steel Creek } \\
\hline & \multicolumn{3}{|c|}{ Stream Order } & \multirow[b]{2}{*}{$84 \& 85^{b}$} & \multirow[b]{2}{*}{$88^{\circ}$} \\
\hline & 2 & 3 & 4 & & \\
\hline Width (m) & 3.7 & 6.7 & 10.6 & 3.5 & 4.8 \\
\hline Depth (m) & 0.27 & 0.40 & 0.91 & 0.22 & 0.51 \\
\hline
\end{tabular}

a Source: (Unpublished data belonging to SRTC/ESS)

b Source: (Aho et al. 1986)

c Source: (Heuer et al. 1989) 
Table 4. Fish assemblage composition in Steel Creek approximately $1 \mathrm{~km}$ downstream from the L Lake dam before and after the impoundment of L Lake.

\begin{tabular}{|c|c|c|}
\hline Species & $\begin{array}{c}\text { Before } \\
\text { impoundment } \\
(1984 / 1985)^{\mathrm{a}}\end{array}$ & $\begin{array}{l}\text { After } \\
\text { impoundment } \\
(1988)^{\mathrm{b}}\end{array}$ \\
\hline
\end{tabular}

yellowfin shiner

41.1

shiner (species unidentified)

40.9

bluehead chub

pirate perch

13.2

spotted sunfish

6.4

mosquito fish

5.9

5.0

tessellated darter

4.3

speckled madtom

3.2

redbreast sunfish

blackbanded darter

2.7

coastal shiner

northern hogsucker

redfin pickerel

chubsucker

2.3

1.9

1.7

1.7

dollar sunfish

tadpole madtom

1.5

1.5

flat bullhead

1.4

1.2

American eel

dusky shiner

largemouth bass

yellow bullhead

margined madtom

Savannah darter

creek chub

brown bullhead

1.2

1.2

0.8

0.6

0.4

0.4

0.3

0.1

eastern mudminnow

0.1

bluegill

spotted sucker

chain pickerel

longnose gar

a Source: (Aho et al. 1986)

b Source: (Heuer and Kissick 1989) 


\section{Figures}

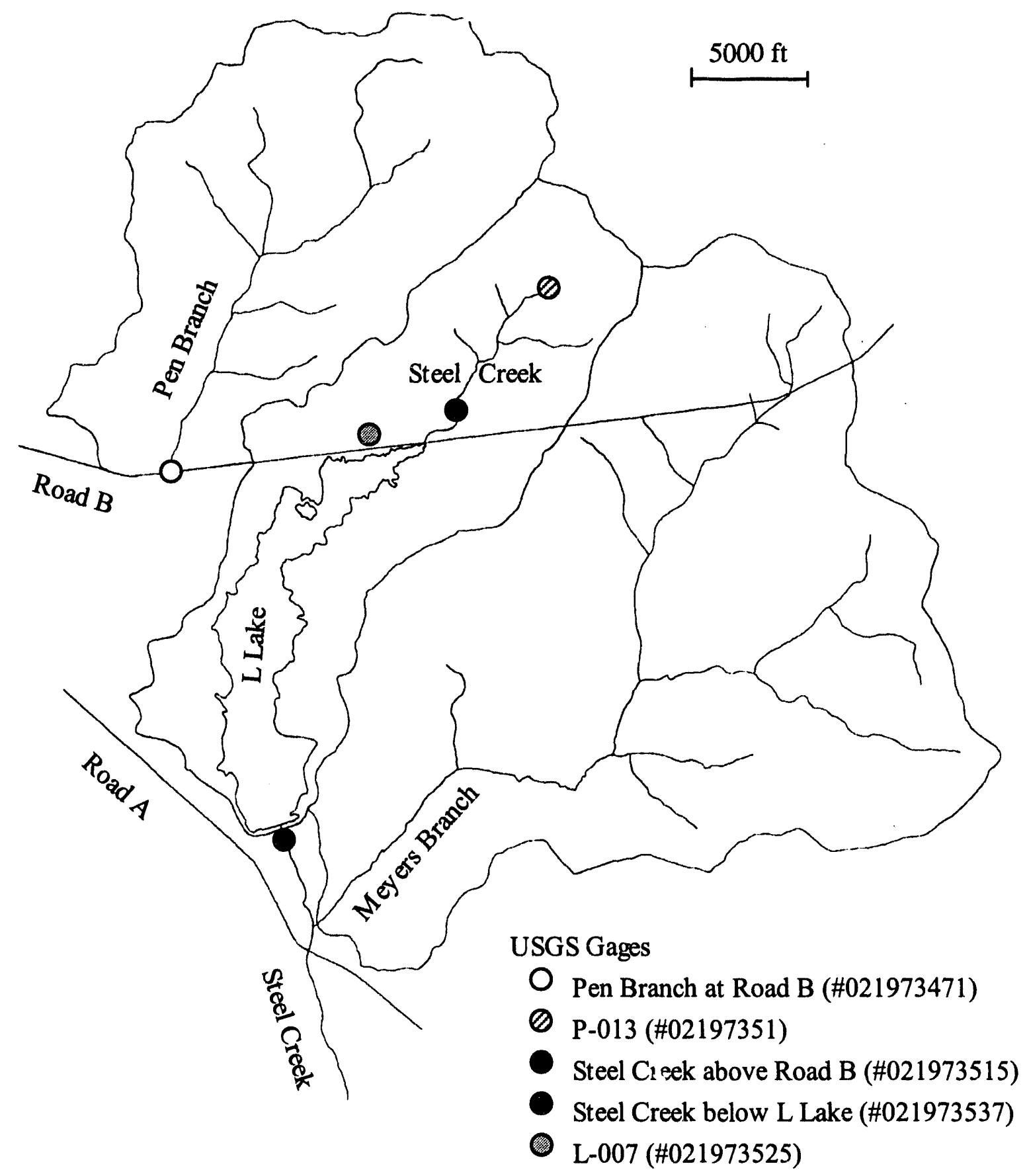

Figure 1: Steel Creek and L Lake Area 

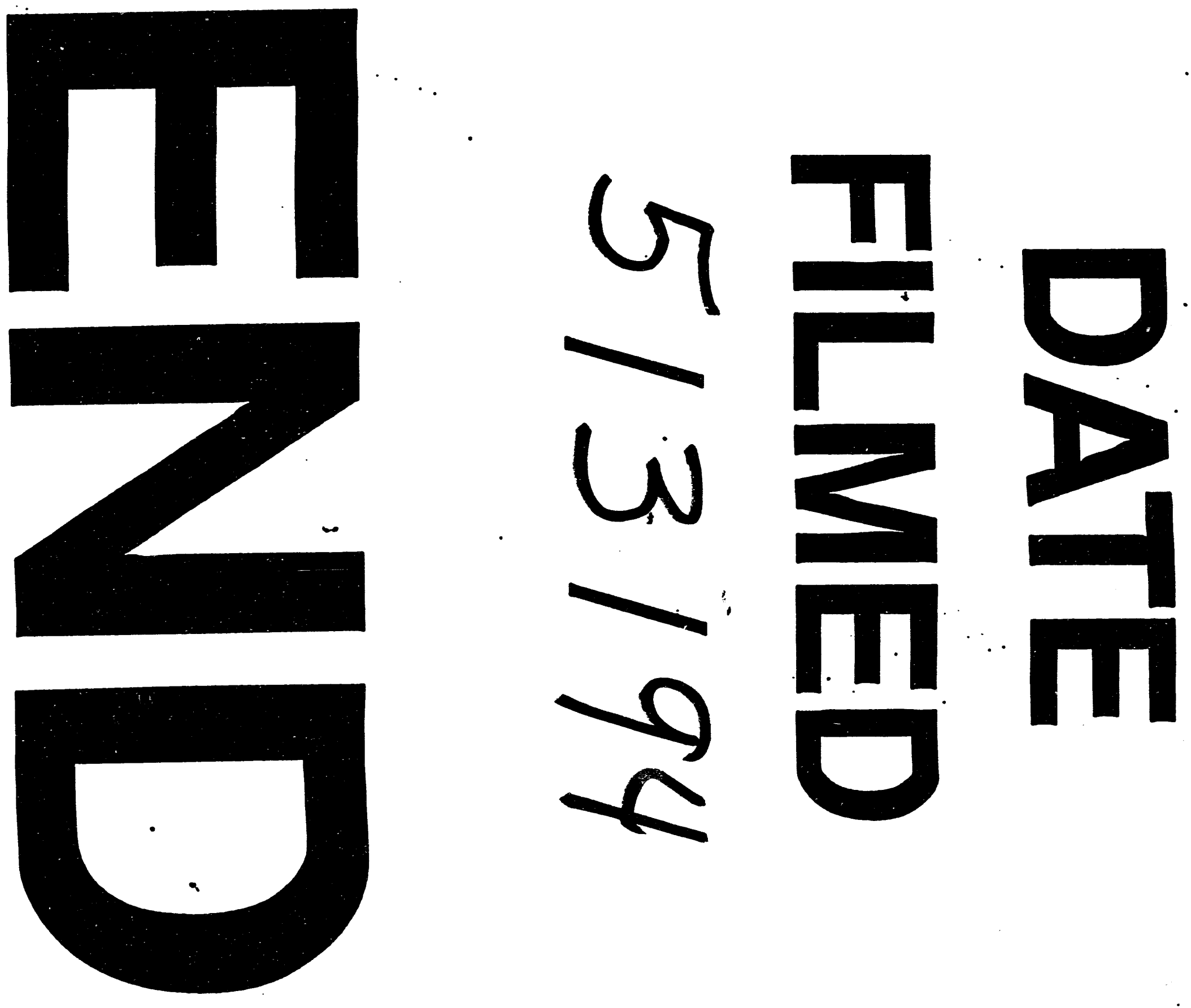
